\title{
Društvene inovacije kao važan element europskih razvojnih strategija
}

SANJA FRANC *

ANTEA BARIŠIĆ

Ekonomski fakultet u Zagrebu

Sveučilište u Zagrebu

Zagreb, Hrvatska

PETRA PALIĆ

Odjel za sociologiju

Hrvatsko katoličko sveučilište

Zagreb, Hrvatska

\author{
Pregledni rad \\ UDK: 364.46 (4-6 EU) \\ doi: 10.3935/rsp.v27i3.1719 \\ Primljeno: ožujak 2020.
}

Zemlje članice Europske unije (EU) prolaze kroz proces ekonomske i demografske transformacije sa znatnim utjecajima na društvo i gospodarstvo. Kako bi se odgovorilo na postojeće i buduće izazove pred zemljama članicama, potrebno je prilagoditi strategije i politike razvoja te staviti naglasak na inovacije, društvene promjene, jednakost i održivi razvoj. Sve više znanstvenika, nositelja ekonomskih politika, nevladinih organizacija i poduzetnika danas pokazuje interes u području socijalnih inovacija te kroz iste nastoji odgovoriti na niz postojećih problema. Cilj je ovog rada istražiti ulogu i načine poticanja socijalnih inovacija u Europskoj uniji. Doprinos rada ogleda se u pregledu značaja socijalnih inovacija te sustavnom prikazu mjera njihova poticanja, postojećih prepreka razvoju te potreba i preporuka za njihov daljnji razvoj s obzirom na suvremene globalne izazove s kojima se EU susreće. Rezultati istraživanja ukazuju na rastuću važnost uloge socijalnih inovacija u okviru suvremenih politika EU-a koja aktivno promiče pristup peterostruke uzvojnice, prepoznajući održivi razvoj i inovacije kao ključne razvojne prioritete u vremenu Četvrte industrijske revolucije. Kao preporuke za daljnji razvoj socijalnih inovacija u EU u radu se ističu potreba za koordinacijom različitih instrumenata EU-a u ovom području, poticanje ulaganja u inovativne programe obrazovanja, usavršavanja i zapošljavanja u ovom području, povećanje svijesti o socijalnim inovacijama, poticanje umrežavanja i širenja informacija te stvaranje poticajnog okruženja za njihov razvoj. Također, u radu se ističu nedostaci u području mjerenja socijalnih inovacija, kao i nužnost adresiranja ovog izazova, u cilju poboljšanja razumijevanja njihove uloge, ali i efikasnije alokacije poticaja istima.

Ključne riječi: socijalne inovacije, Europska unija, strateški okvir, razvojne strategije.

* Sanja Franc, Ekonomski fakultet u Zagrebu, Sveučilište u Zagrebu, Zagreb, Hrvatska / The Faculty of Economics \& Business, University of Zagreb, Trg J.F. Kennedy 6, HR-10000 Zagreb, Croatia, sfranc@efzg.hr 


\section{UVOD}

Posljednja su desetljeća obilježena velikim promjenama koje su posljedica brzog razvoja tehnologija, migracija i, općenito, jačanja procesa globalizacije. Kako bi se adresirao niz novonastalih promjena, nužne su inovacije u različitim sferama. Inovacije su često odgovori na društvene probleme koje ne zadovoljavaju postojeći ili tradicionalni institucionalni pristupi. Budući da se inovacije smatraju važnim pokretačem razvoja svjetskoga gospodarstva (Solow, 1957.; Romer, 1986.; Nadiri, 1993.; Hasan, 2010.; Heiskala, 2007.), ali i kvalitete života (Mumford i Moertl, 2003.), potrebno je stvoriti okruženje koje će poticajno djelovati na njihovo stvaranje i diseminaciju. Inovacijski sustavi i inovacijske politike trebaju biti usklađeni s nacionalnim uvjetima i potrebama. Politike poticanja inovacija razlikuju se među zemljama različitih razina razvoja budući da se institucionalna infrastruktura, razina obrazovanja, aktivnosti istraživanja i razvoja i drugo uvelike razlikuju. Tako se inovacijske politike mogu usmjeriti, primjerice, na temeljna ulaganja u tehnološku infrastrukturu, razvoj temeljnih inovacija koje bi doprinijele blagostanju, obrazovanju ili poljoprivrednom razvoju, na razvoj potpuno novih aktivnosti temeljenih na primjeni informacijske tehnologije ili na razvoj autonomnih institucija zaduženih za poticanje inovacije i stvaranje klastera, ili na jačanje znanstvene baze. U razvijenim zemljama jačanje nacionalne inovacijske baze smatra se prioritetom. Flanagan i sur. (2011.) ističu da uspjeh inovacijskih politika ovisi jednako o odabiru instrumenata, koliko i o samoj implementaciji tih instrumenata. Također, politika, mjere i instrumenti mogu biti prikladno odabrani i pravilno implementirani, no rezultat može izostati uoči nepovoljnog šireg okvira razvoja.

U razdoblju od posljednje svjetske financijske krize sve više u fokus istraživanja te ekonomskih i inovacijskih politika dolazi relativno novi koncept socijalnih inovacija (primjerice Wijk i sur., 2019.; Avelino i sur., 2019.; Moulaert, 2016.). Štoviše, širenje socijalnih inovacija u bogatim zapadnim ekonomijama u godinama nakon globalne financijske krize ukazuje na važnost ovog koncepta inovacija. Iako postoji niz definicija socijalnih inovacija (primjerice, Phills i sur., 2008.; Murray i sur., 2010.; Neumeier, 2012.), u najširem smislu možemo reći da se pod istima podrazumijevaju one inovacije koje nude rješenja za različite društvene izazove i potrebe (The Economist, 2016.). Kao njihov glavni cilj postavlja se mobiliziranje kreativnosti članova zajednice u cilju pronalaženja rješenja za raznolike izazove i potrebe koji omogućavaju bolje korištenje oskudnih resursa (Avelino i sur., 2019.). Pri tom se podrazumijeva rastuća uloga sudjelovanja građana i socijalnih poduzetnika u reformi nacionalnih inovacijskih sustava (Avelino i sur., 2019.). Socijalne inovacije pojavljuju se u istraživanjima na području razvoja, društtva i društvenih promjena, psihologije i kreativnosti (van der Have i Rubalcaba, 2016.).

Fokusirajući se na Europsku uniju, valja primijetiti da zemlje članice prolaze kroz proces ekonomske i demografske transformacije sa znatnim utjecajima na društvo i gospodarstvo. Kako bi se odgovorilo na postojeće i buduće izazove pred zemljama članicama, potrebno je prilagoditi strategije i politike razvoja te staviti naglasak na koncepte poput inovacija, društvenih promjena, jednakosti, održivog razvoja i slično. U tom smislu, socijalne inovacije predstavljaju suvremene odgovore na društvene potrebe kojima se utječe na proces društvenog djelovanja uz glavni cilj unapređenja društvenog blagostanja. Štoviše, u posljednjih desetak godina socijalne su inovacije dobile važno mjesto u razvojnim strategijama (Adams i Hess, 2010.; Neumeier, 2012.; Grimm i sur., 2013.; Bosworth i sur., 2016.). 
Tijekom desetljeća mijenjala se i prilagođavala krovna strategija EU-a. Lisabonska strategija bila je usmjerena na rast, zaposlenost, inovacije i poduzetništvo, a strategija Europa 2020 dodatno uključuje socijalne inovacije, energiju, održivi razvoj i klimatske promjene, dok je nova strategija za razdoblje do 2030. godine usmjerena na održivi razvoj i energiju. Najnovija strategija EU-a usmjerena je na kreiranje europskog društva kao konkurentnog, sigurnog i energetski učinkovitog sustava, spremnog za dostizanje dugoročnog cilja smanjenja emisija stakleničkih plinova do 2050. godine. U skladu s globalnim trendovima, EU mora usmjeriti napore na odražavanje ravnoteže između društvenog i ekonomskog razvoja uz očuvanje ekosustava. Socijalne inovacije postaju tako sve popularniji instrument postizanja ovih ciljeva i važan element strategija razvoja.

Cilj ovog rada je istražiti ulogu i načine poticanja socijalnih inovacija u EU. Koristeći primjer EU-a, ovaj rad proučava strateški okvir i mjere koje je EU uvela kako bi podržala inovacije, posebno socijalne inovacije koje su dio šireg modela peterostruke uzvojnice (eng. five-helix model) (Carayannis i sur., 2012.). Ovaj rad daje pregled postojećih relevantnih istraživanja, studija, strategija i drugih dokumenata. Osim pregleda ključnih dokumenata i inicijativa u ovom području, u radu su analizirane ključne prepreke i izazovi u razvoju socijalnih inovacija te su dane preporuke za buduće korake. Pri tom su primijenjene znanstvene metode analize, sinteze, kompilacije i dedukcije. Metodama analize, sinteze i kompilacije koristilo se u cilju sustavnog prikaza i razumijevanja poticanja inovacija općenito i socijalnih inovacija u EU te za otkrivanje ključnih prepreka njihovu razvoju. Deduktivnom metodom doneseni su zaključci o značaju socijalnih inovacija i preporukama za njihov daljnji razvoj na području EU-a kako bi se omogućilo njihovo šire razumije- vanje u kontekstu ekonomskog i društvenog napretka uz ostvarenje održivog razvoja.

Doprinos rada ogleda se u pregledu značaja socijalnih inovacija te sustavnom prikazu mjera njihova poticanja, prepreka razvoju te potreba i preporuka za njihov daljnji razvoj s obzirom na suvremene globalne izazove s kojima se EU susreće.

Rad se sastoji od pet dijelova. Prvi dio rada je uvod iza kojeg slijedi pregled dosadašnjih istraživanja iz ovog područja kao teorijska podloga istraživanja u okviru ovog rada. U trećem su dijelu istražene inicijative za poticanje inovacija u EU. U četvrtom dijelu rada analiziraju se implementirane inicijative Europske unije za razvoj socijalnih inovacija i potencijalne prepreke njihovu razvoju te se daju preporuke za budući razvoj društvenih inovacija. Posljednji, peti, dio je zaključak u kojem su sažeta najvažnija saznanja iz rada te se daju preporuke za razvoj socijalnih inovacija i daljnja istraživanja u području.

\section{DOSADAŠNJA ISTRAŽIVANJA KAO TEORIJSKA PODLOGA}

\section{Definiranje i razvoj socijalnih inovacija}

Novi inovacijski obrasci nerijetko se prepoznaju u socijalnim inovacijama koje nastaju kada se pronađu nova rješenja za društvene izazove. Socijalne inovacije nisu nova pojava, no njihovo pojmovno određenje još uvijek nije jednoznačno. Sve veća potreba za socijalnim inovacijama javila se usporedno s jačanjem procesa globalizacije i bržeg razvoja tehnologija koji su imali višestruke i raznolike učinke na društvo i gospodarstvo. U suvremenom digitalnom dobu uz sve širu primjenu digitalnih tehnologija osobito je primjetan jaz između postojećih i potrebnih vještina radne snage. Tradicionalni poslovi polako nestaju, a razvijaju se nova zanimanja i zadaci. Niz društvenih izazova koji se pritom pojavlju- 
ju predstavlja ujedno i prilike za uspostavu novih strategija, politika, suradnji, prioriteta i instrumenata za učinkovito ostvarenje postavljenih ciljeva. Važno je stoga naglasiti da su socijalne inovacije nerijetko posljedica suradnje između različitih sektora te da one mogu nastati u različitim sektorima (Angelidou i Psaltoglou, 2017.).

Najveće razlike pri definiranju socijalnih inovacija proizlaze upravo iz objašnjenja značenja riječi »socijalne«. Phills i sur. (2008.) smatraju da su inovacije socijalne samo ako prevlada socijalna vrijednost, odnosno korist za društvo u cjelini, a ne korist privatnog sektora, odnosno poduzetnika, ulagača i kupaca. Murray i sur. (2010.) socijalne inovacije definiraju kao nove ideje koje zadovoljavaju socijalne potrebe i stvaraju nove društvene odnose, pri čemu naglašavaju važnost zadovoljavanja nezadovoljenih potreba. Socijalne inovacije mogu se opisati i kao društvena ostvarenja koja, u usporedbi s postojećim rješenjima, pružaju nova poboljšana rješenja koja su u manjoj mjeri određena u smislu apsolutne inovativnosti, a više u smislu posljedica koje nose (Neumeier, 2012.). Pol i Ville (2009.) poželjne socijalne inovacije definiraju kao one koje poboljšavaju kvalitetu života na makrorazini ili povećavaju životni vijek. Pritom pod makropokazatelje kvalitete života ubrajaju pokazatelje na razini skupine ljudi koji obuhvaćaju: materijalno bogatstvo, mogućnosti obrazovanja, dostupnost i kvalitetu zdravstva, sigurnost posla, život u zajednici i obitelji, okoliš, političke slobode, političku stabilnost i sigurnost i rodnu ravnopravnost.

OECD (2010.) naglašava da se socijalne inovacije razlikuju od ekonomskih jer se ne temelje na uvođenju novih vrsta proizvodnje ili iskorištavanju novih tržišta, nego se usmjeravaju na zadovoljavanje novih potreba koje tržište nije zadovoljilo ili na stvaranje novih i boljih načina »uključivanja« ljudi, u smislu davanja ljudima uloge u procesu proizvodnje.
Dodatno se prilikom definiranja socijalnih inovacija i njihove razlike u odnosu na druge pojmove naglašavaju naredni kriteriji koje valja zadovoljiti (Tepsie, 2014.):

- zadovoljavaju socijalne potrebe, odnosno mogu pomoći pri artikuliranju ili oblikovanju postojećih potreba te prepoznavanju novih potreba ili onih koje dosad nisu bile prepoznate, razlikujući se tako od inovacija koje imaju socijalni učinak

- stavljene su u upotrebu te ih upravo primjena razlikuje od društvenih izuma pod kojima se podrazumijevaju ideje koje još nisu implementirane

- uključuju i mobiliziraju korisnike, bilo izravno ili putem posrednika ili drugih dionika, što osigurava ispunjavanje pravilnih ciljeva i uključivanje članova ciljnih skupina pri rješavanju problema koje imaju, omogućavajući pristup boljim i kvalitetnijim rješenjima te povećanju svijesti i unapređenju kompetencija.

- mijenjaju društvene odnose poboljšavajući pristup moći i resursima te pružajući mogućnost osnaživanja određenih društvenih skupina i promjenu nepravedne distribucije moći i resursa u društvu.

Socijalne inovacije nastaju iz novih praksi koje se obično razvijaju pristupom odozdo prema gore. Kako bi se inovacije smatralo socijalnima, ključnima se smatraju i sljedeći kriteriji (Spiesberger i sur., 2018.): novitet, društveno obilježje intervencije, održivost primjene te značajan učinak na društvo. Očekivani ishod socijalnih inovacija je, između ostalog, stvaranje društvene vrijednosti. Emerson, Wachowicz i Chun (2000.) objašnjavaju da se društvena vrijednost stvara kada se resursi, inputi, procesi ili politike koriste na način da se ostvari poboljšanje u životnom standardu pojedinaca ili društva u cjelini. Prema Gentile (2000.), socijalni učinci odražavaju i prate složenu međuovisnost poslovne prakse 
i društva. Clark i sur. (2004.) definiraju socijalni učinak kao dio cjelokupnog ishoda koji se dogodio kao rezultat aktivnosti organizacije, iznad i izvan onoga što bi se ionako dogodilo.

Socijalne inovacije mogu se razviti na više razina i u različitom obuhvatu. Nicholls i Murdock (2012.) razlikuju tri vrste socijalnih inovacija: (1) inkrementalne, koje su usmjerene na proizvode i usluge; (2) institucionalne, koje su usmjerene na tržišta i (3) razorne inovacije, koje su usmjerene na političke ili društvene pokrete. Nadalje, što se obuhvata tiče, moguce je razlikovati socijalne inovacije koje uključuju određene niše, režime ili čitavo okruženje koje uključuje ekonomske cikluse, političke aranžmane i društvene trendove, a zapravo su slične podjeli na mikro, mezo i makrorazinu. Postoje mišljenja da uz socijalne inovacije koje obuhvaćaju čitav sustav ne treba zanemariti inovacije na lokalnoj razini budući da i one mogu mnogo doprinijeti društvu, iako su kraćeg vijeka. Bežovan i sur. (2016.) pritom posebnu važnost pridaju velikim gradovima koje smatraju epicentrima tenzija ostvarivanja ekonomske i socijalne ravnoteže u razvoju. Navedenu tezu potvrđuju i Angelidou i Psaltoglou (2017.) s obzirom da upravo u gradskom okruženju često socijalne inovacije omogućavaju rješenje problema za koje javni i privatni sektor nisu uspjeli ponuditi rješenja. Ipak, kapaciteti socijalnih inovacija često su povezani s politikama i ostalim karakteristikama gradova (Baturina, 2014.).

Prema Reynolds, Gabriel i Heals (2016.), politika može imati dvojaku ulogu u pogledu socijalnih inovacija. S jedne ih strane može poticati, dok s druge strane, i sama politika može biti socijalna inovacija. U prvom slučaju, javna politika može poboljšati ponudu i potražnju za socijalnim inovacijama, kao i stvaranje šireg okruženja u kojem socijalne inovacije mogu napredovati. To nazivamo »politikom socijalnih inovacija«. Također, kreiranje politika može biti druš- tveno inovativni proces kada usvaja načela i alate socijalnih inovacija, što se naziva »politika kao socijalna inovacija«.

\section{Inovacije, rast i razvoj}

Ekonomski rast zemlje može se ostvariti na više različitih načina, ali se najčešće ogleda kao posljedica povećanja raspoloživih proizvodnih faktora, njihove efikasnije alokacije u gospodarstvu ili je pak posljedica inovacija koje podrazumijevaju stvaranje novih proizvoda ili novih načina uporabe postojećih proizvoda, točnije efikasnije uporabe postojećih inputa (Heiskala, 2007.). Doprinos inovacija ekonomskom rastu je široko istražen u znanstvenoj literaturi. Još 1939. godine Schumpeter je dao važan doprinos izučavanju gospodarskog rasta te razlikuje rast od ekonomskog razvoja. S njegovog stajališta, ekonomski rast predstavlja sporo i progresivno mijenjanje ekonomskog sustava, koje je rezultat egzogenih čimbenika ekonomskog sustava, a s druge strane, ekonomski razvoj koji se generira neprekidnim internim promjenama uzrokovanim ekonomskim inovacijama, dolazi iz ekonomskog sustava. Solowljev neoklasični model ekonomskog rasta (1957.) stavlja naglasak na važnost tehnološkog napretka, odnosno inovacija, uz povećanje inputa. Prema Romeru (1986.), inovacije su egzogene u modelu rasta i nastaju kao posljedica prelijevanja znanja. U Romerovu pristupu ključno je stvaranje novog znanja koje generira eksternalije, a koje se poistovjećuje s pojmom tehnološkog napretka. Lucasov se model (1988.) temelji na investicijama u ljudski kapital, čiji se efekt prelijevanja odražava u višoj razini razvijenosti tehnologije, a posljedično tome, i u višoj razini inovacijskih aktivnosti. Različita istraživanja su također pokazala povezanost između količine i kvalitete inovacija i porasta BDP-a per capita, pritom ističući važnost istraživanja i razvoja i patenata u gospodarstvu (Ulku, 2004.; Hasan, 2010.). 
U kontekstu doprinosa inovacija ekonomskom rastu stoga je jasno da tehnologija koja se najčešće povezuje s inovacijskim aktivnostima predstavlja važnu determinantu istog.

Dosadašnje industrijske revolucije omogućile su zemljama da povećaju ekonomski rast, produktivnost i blagostanje, no pri tom je došlo do porasta nejednakosti kako među zemljama tako i unutar zemalja te se pojavio niz novih izazova na koje je potrebno odgovoriti. Sve češće se od 1990-ih spominje važnost inkluzivnog socijalnog i ekonomskog razvoja, posebice kroz područje istraživanja održivog razvoja (Midgley, 1995.; Griggs i sur., 2013.; Sachs, 2015.; Astakhova i sur., 2016.). Također, smatra se da tehnološke inovacije stimuliraju socijalne inovacije, ali i obrnuto (Buhr, 2015.).

Četvrta industrijska revolucija donosi niz revolucionarnih tehnoloških napredaka, ali i izazova, s obzirom da će automatizacija učiniti dio radnih mjesta suvišnima te će se zahtijevati različite nove vještine i znanja koje radnici na rutinskim poslovima rijetko već posjeduju. Kako bi se adresiralo ove i ostale izazove, potreban je holistički pristup, s obzirom da tehnološka i poslovna inovativna rješenja nisu dostatna te se stoga naglašava iznimna važnost socijalnih inovacija u ovom kontekstu (Morrar et al., 2017.). Buhr (2015.) naglašava da je nužno da Četvrta industrijska revolucija bude više od tehnološke revolucije te da socijalne inovacije budu njen integralni dio. Stoga se implicitno postavlja očekivanje da socijalne inovacije budu dio politika rasta $\mathrm{i}$ razvoja zemalja. Imperativ socijalnih inovacija u suvremenom okruženju posebice je naglašen kroz UN-ove ciljeve održivog razvoja do 2030. godine na koje su se obvezale njegove zemlje članice. U okviru istih naglašava se postizanje ravnoteže između socijalne, ekonomske i okolišne održivosti (UN, 2015.).

\section{POTICANJE INOVACIJA U EUROPSKOJ UNIJI}

Europska unija s višerazinskim sustavom upravljanja i supranacionalnim institucijama predstavlja svjetskog predvodnika u osmišljavanju rješenja za nove društvene, ekonomske i političke izazove. Od trenutka osnivanja, EU je bila primjer duboke integracije i pokretača promjena te je sposobnošću stvaranja inovativnih rješenja za postizanje društvene jednakosti i pružanja kvalitetnih usluga stvorila jedinstven identitet. Poticanje uključenosti, konkurentnosti i održivog razvoja temelj su dosadašnje razvojne strategije s ciljem da EU postane pametna, održiva i inkluzivna ekonomija. U posljednjih nekoliko desetljeća sve se više pažnje pridaje jačanju održivosti, inkluzivnosti i inovativnosti. Lisabonska strategija donesena je zato što je Europa trebala ekonomske i socijalne reforme da bi postigla održivi uspjeh u uvjetima globalizacije kako bi konkurirala SAD-u te rastućim ekonomijama poput Brazila, Indije i Kine. Lisabonskom strategijom iz 2000. godine Europska unija htjela je, dakle, sustići svoje globalne konkurente te osigurati uspješnu budućnost EU-a i njezinih građana. Stope zaposlenosti u EU bile su niže, a dugoročna strukturna nezaposlenost bila je kontinuirani problem. Zbog visoke nezaposlenosti i starenja stanovništva, europski mirovinski sustavi tada više nisu bili održivi (Höpker, 2013.). Nakon pet godina, Europsko vijeće revidiralo je i preusmjerilo ciljeve Lisabonske strategije i 2005. godine donesena je revidirana strategija koja se trebala usredotočiti na sljedeća tri područja: (1) znanje i inovacije; (2) stvaranje Europe boljim mjestom za investiranje i posao te (3) rast i zapošljavanje za veću socijalnu koheziju. Usporedbom zadanih ciljeva i rezultata ostvarenih 2010. godine, može se reći da Lisabonska strategija nije uspješno provedena jer kvantitativni ciljevi povezani s ekonomskim rezultatom, zapošljavanjem, istraživanjem i inovacijama, socijalnom kohezijom i održivim razvojem 
nisu ostvareni (Höpker, 2013.). Ne može se reći da provedbom Lisabonske strategije nije ispunjena nijedna njezina zadaća, ali osnovni cilj stvaranja »najkonkurentnije i najdinamičnije ekonomije u svijetu, sposobne za održivi ekonomski rast s više poslova i boljim poslovima te većom socijalnom kohezijom istodobno zasnovane na znanju « nije ostvaren. Smatra se da su glavni razlozi neuspjeha Lisabonske strategije ukorijenjeni u njenoj upravljačkoj strukturi (Höpker, 2013.).

Godine 2010. Europska je unija donijela novu strategiju pod nazivom Europa 2020. Prioriteti Europe 2020 bili su osigurati pametan rast zasnovan na znanju, inovacijama i digitalnom društvu, održivi rast zasnovan na konkurentnosti, borbi protiv klimatskih promjena i učinkovitosti iskorištavanja resursa te uključiv rast koji promovira visoku zaposlenost, bolje vještine te socijalnu i teritorijalnu koheziju (Höpker, 2013.). Iz toga je vidljivo da je rast glavni cilj strategije, $s$ jedne strane nadilaženje problema nastalih uslijed krize, a s druge strane osiguravanje dugoročne održivosti europske ekonomije.

Tijekom godina najveći dio proračuna EU-a bio je usmjeren na poljoprivredu i koheziju (oko 70\%) (European Commission, 2016.). Buduća ulaganja usmjerena su na područja istraživanja i razvoja, mobilnost mladih, transportne i energetske mreže, vanjske odnose i djelovanje. Poticanje konkurentnosti gospodarstva i jačanje inovacijskog potencijala i tehnološkog razvitka gospodarstva putem povezivanja sa sveučilištima i istraživačkim centrima radi komercijalizacije znanstvenih dostignuća samo su neki od prioriteta EU-a. Europska je komisija stavila na raspolaganje različite politike, pravne mjere i propise svojim zemljama članicama u cilju poticanja ulaganja $\mathrm{i}$ inovacija te kontinuirano radi na razvoju instrumenata za poticanje inovacija, koji uključuju strukturne fondove, Okvirni program za istraživanje i razvoj i Okvirni program za konkurentnost $\mathrm{i}$ inovacije i drugo. Nadalje, Europska je komisija predložila i nekoliko inicijativa, poput inicijative »Mladi u pokretu«, »Digitalna agenda za Europu«, »Resursno učinkovita Europa«, s ciljem povećanja međunarodne privlačnosti europskih institucija visokog obrazovanja, podizanja kvalitete visokog obrazovanja, osiguranja ekonomske i socijalne koristi od jedinstvenog digitalnog tržišta te postizanja održivog razvoja i racionalnog korištenja energije. Zajednički centar za istraživanja (eng. Joint Research Centre) osnovan je s ciljem podupiranja i poticanja širenja tehnologije na području EU-a. Europski institut za tehnologiju (EIT) ima važnu ulogu u promicanju inovacija. Prošle je godine predložen novi strateški program za poticanje inovacija. Taj će se program uskladiti s programom EU-a za istraživanje i inovacije za naredno razdoblje (Obzor 2021.-2027.), ispunjavajući njegovu obvezu za daljnjim jačanjem europskog inovacijskog potencijala. EIT će financirati aktivnosti postojećih i novih zajednica znanja i inovacija i podržati inovacijski kapacitet 750 visokih učilišta.

Zemlje članice prepoznale su važnost istraživanja i razvoja i ulaganja u tehnologije te razvijaju vlastite politike razvoja tih područja s krajnjim ciljem transformacije u ekonomije znanja i inovacija. 
Slika 1.

Planirana ulaganja EU-a u istraživanje i razvoj

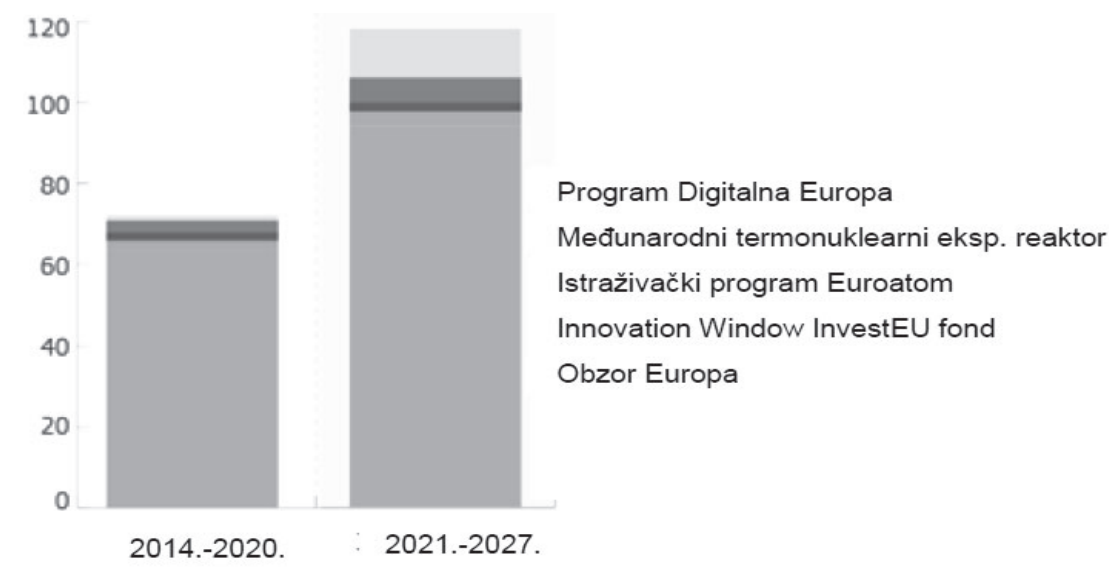

Izvor: izrada autora prema European Commission (2018.)

Spomenuti Okvirni programi za istraživanje i tehnološki razvoj, koji se skraćeno nazivaju Okvirni programi (eng. Framework Programe - FP), predstavljaju programe koje je kreirala Europska unija za potporu i poticanje istraživanja na Europskom istraživačkom području. Interim vrednovanje posljednjeg programa Obzor 2020 (ili FP8) pokazuje da je postignut značajan napredak u pojednostavljenju okvirnih programa te su alocirana sredstva također povećana. Istraživanje i inovacije u biti su zajednički pothvati, gdje se najveći napredak može postići kada različite skupine surađuju kako bi se sredstva i znanje udružili za rješavanje problema. Sljedeći okvirni program FP9 (obuhvaća najveći udio ulaganja na Slici 1.) ima važnu ulogu pri uklanjanju zapreka novim sudionicima, održavanju otvorenosti prema društvu te poticanju suradnje i dijeljenja znanja (Department for Business, Energy \& Industrial Strategy, 2018.). Predložena proračunska sredstva za I\&R u iznosu od 100 milijardi eura za razdoblje 2021. - 2027. uključuju 97,6 milijardi eura za Obzor Europa (od kojih će 3,5 milijardi eura biti dodijeljeno u okviru fonda Invest EU) i 2,4 milijarde eura za Program Euratom za istraživanje i osposobljavanje (Slika 1.). Oba programa promicat će sinergijsko djelovanje s drugim budućim programima i politikama EU-a kako bi se potaknulo brže širenje na nacionalnoj i regionalnoj razini te prihvaćanje istraživačkih i inovacijskih rezultata.

Neke se zemlje ističu više od drugih na području znanosti i tehnologije unatoč istoj razini ulaganja. U pojedinim zemljama izazov povećanja učinkovitosti započinje s reformama koje su potrebne kako bi se postigla znanstvena i tehnološka izvrsnost. Za druge pak zemlje glavni je izazov pokretanje brzorastućih inovativnih poduzeća i međunarodna konkurentnost stečena širenjem znanja. Gotovo sve zemlje EU-a pokrenule su velike reforme politika u cilju povećanja efikasnosti i efektivnosti sustava istraživanja i razvoja. Među najuspješnije zemlje u inoviranju mjereno prema European Innovation Scoreboard ubrajaju se Švedska, Nizozemska, Luksemburg te Belgija, dok su najslabiji inovatori Rumunjska, Bugarska i Hrvatska (Slika 2.). 
Slika 2.

Poredak zemalja prema Europskoj ljestvici uspjeha u inoviranju, 2018.

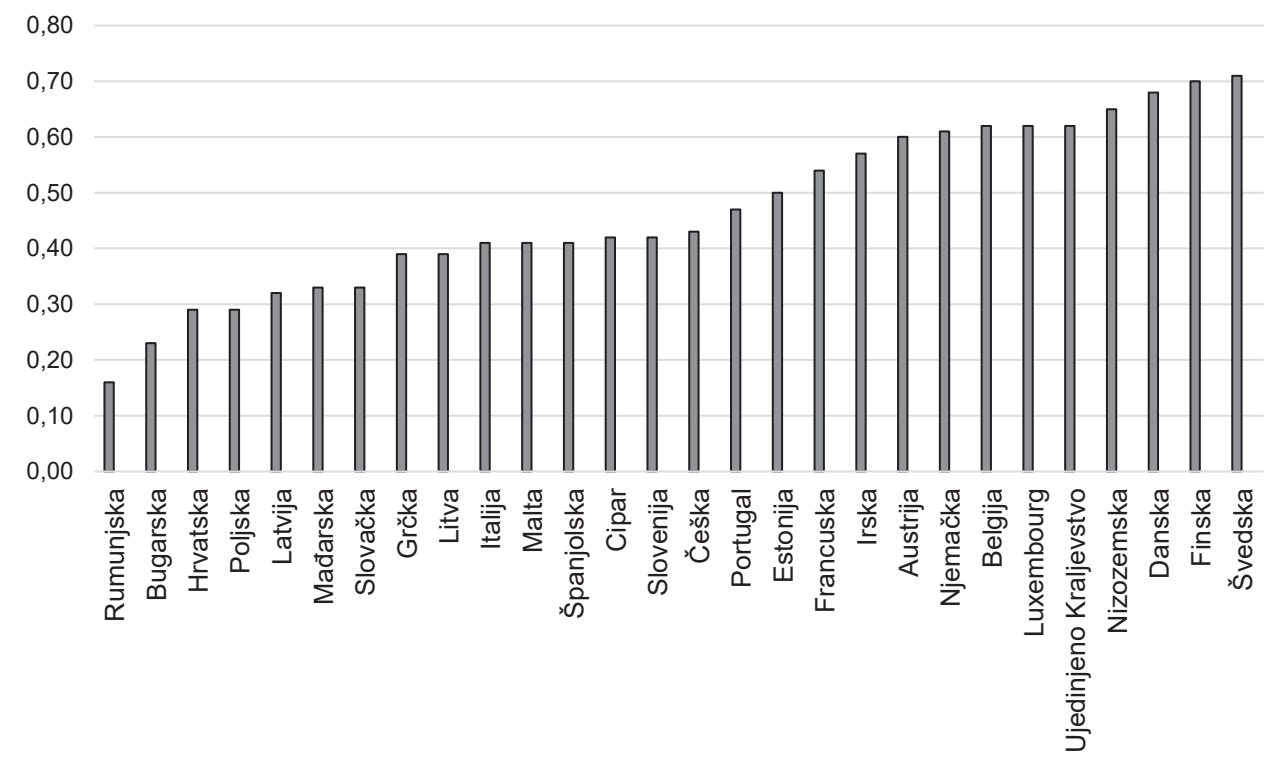

Izvor: izrada autora prema European Commission (2019.)

Unija inovacija bila je odgovor EU-a na globalnu financijsku krizu. To je način stvaranja radnih mjesta i rasta kroz istraživanje i inovacije. Predstavlja ujedno i jednu od sedam glavnih inicijativa strategije Europa 2020. U cilju poticanja inovacija te stjecanja znanja i potrebnih vještina, Europska komisija preporučuje izgradnju čvrste suradnje između ministarstva zaduženog za znanje i obrazovanje, ministarstva zaduženog za gospodarstvo i industrije, kako bi se postigli sinergijski učinci i osigurali preduvjeti za razvoj. Većina je zemalja članica pokrenula inicijative u smjeru izgradnje partnerskog odnosa vlade $\mathrm{i}$ industrije kako bi se kreativne djelatnosti stavile u središte strategije rasta i razvoja. Prepoznata je važnost obrazovnog sustava koji potiče mlade kreativce na izražavanje i usavršavanje svojih vještina i usmjerava ih prema kreativnim djelatnostima (European Commission, 2013.).
Zapošljavanje i socijalni izazovi s kojima se Europa suočava u velikoj su mjeri posljedica relativno skromnog rasta koji je rezultat neiskorištenog potencijala u smislu zapošljavanja i produktivnosti. Budući da su gospodarski i socijalni napredak povezani, uspostava Europskog stupa socijalnih prava, jačanje europske konkurentnosti i poticanje ulaganja, otvaranje radnih mjesta i socijalna kohezija, trebalo bi biti dio sveobuhvatnijih napora u izgradnji inkluzivnijeg i održivijeg modela rasta. Bit je Europskog stupa socijalnih prava osiguravanje novih i djelotvornijih prava građanima. Temelji se na 20 ključnih načela, razvrstanih u tri kategorije: (1) jednake mogućnosti i pristup tržištu rada, (2) pravedni radni uvjeti i (3) socijalna zaštita i uključenost. Europskim stupom socijalnih prava nastoje se postići učinkoviti rezultati u području zapošljavanja i socijalnih prava kao odgovor na postojeće 
i buduće izazove koji su izravno usmjereni na ispunjavanje osnovnih ljudskih potreba te osiguravanje boljeg ostvarivanja i provođenja socijalnih prava (Tajani i sur., 2017.).

Iz navedenog je vidljivo da je EU društveni napredak, inovacije i održivi razvoj postavila na vrh svojih razvojnih prioriteta. Kako bi se postigao cilj održive Europe, svi akteri moraju biti uključeni u različite domene politike, poput obrazovanja, financija, društvene odgovornosti poduzeća, trgovine, upravljanja i vanjske politike.

\section{SOCIJALNE INOVACIJE KAO RJEŠENJE DRUŠTVENIH IZAZOVA U EUROPSKOJ UNIJI}

Socijalne inovacije obično su motivirane socijalnom misijom, a vrijednost koju stvaraju nužno je zajednička društvena i ekonomska vrijednost svih uključenih sudionika (Păunescu, 2014.). Lubelcová (2012.) ističe da je socijalni kontekst inovacija utjecao na način na koji se inovacije doživljavaju; podrazumijevajući ih ne samo kao alat i izvor gospodarskog rasta i konkurentnosti, već i kao potencijalni alat za postizanje socijalnih ciljeva i socijalne kohezije u društvu. U pronalaženju rješenja izazova suvremenog društva i u cilju poboljšanja životnog standarda građana, glavni pokretač svih inovacija trebao bi biti društveni, a ne ekonomski interes. Pritom Pol i Ville (2009.) ističu da bi upravo vlade i privatne interesne grupe mogle igrati ključnu ulogu $\mathrm{u}$ institucionaliziranju socijalnih inovacija kroz poticaje socijalnim investitorima.

S obzirom na brojne promjene u suvremenom globalnom okruženju, potrebna su nova rješenja s posebnim naglaskom na socijalne izazove. Ekonomska kriza, nezaposlenost i starenje stanovništva, povezano $\mathrm{s}$ rastućim troškovima u zdravstvu, samo su neki od uzroka novih potreba građana. Europska unija kao ključne socijalne i gospodarske izazove prepoznaje sljedeće (Social innovation exchange i Young Foun- dation, 2010.): postizanje gospodarskog rasta, borba protiv nezaposlenosti, klimatske promjene, starenje stanovništva, socijalna isključenost te inovacije $\mathrm{u}$ javnom sektoru.

Istraživanjem socijalnih inovacija, njihovih karakteristika i održivosti u kontekstu urbanih socijalnih sustava kroz projekte kao što je, primjerice, projekt Welfare innovations at the local level in favour of cohesion (WILCO) FP7, EU je težila dati novi zamah razvoju socijalnih inovacija (Baturina, 2014.). U okviru navedenog istaknuta je potreba za suradnjom među projektima o pitanju definiranja socijalnih inovacija, ali i niz preporuka za daljnja istraživanja. Jačanje socijalne kohezije i smanjenje nejednakosti jedan je od značajnijih političkih izazova EU te je stoga mogućnost mjerenja socijalnih inovacija nužan alat za njihovo adresiranje (Baturina i Bežovan, 2015.).

U skladu s navedenim, ključni trendovi u razvoju socijalnih inovacija uključuju (Addarii i Lipparini, 2017.): izgradnju institucionalnog kapaciteta i blagostanje, održavanje demokracije i povjerenja, promišljanje o radnim mjestima za budućnost internetske tehnologije, projekte urbane obnove te globalnu međuovisnost. Gospodarstvenici, znanstvenici i istraživači već dugi niz godina naglašavaju važnost inovacija, istraživanja i razvoja pri rješavanju navedenih izazova. Danas se dodatno naglasak stavlja na društvene i ekološke izazove te važnost uključivanja civilnog društva u pronalaženju rješenja za navedene probleme. Sve su više potrebne inovacije usmjerene na društvo i na korisnike što zahtijeva promjenu načina razvoja inovacija. Novi trendovi u inoviranju stoga uključuju (Social innovation exchange i Young Foundation, 2010.): stvaranje vrijednosti u suradnji s korisnicima i stjecanje novih znanja o njima; iskorištavanje globalnog znanja i mreža suradnje; promatranje globalnih izazova kao poticaja za inovacije; promatranje izazova u javnom sektoru kao izvora inovacija. Rastuće socijalne potrebe zajedno s ograničenim prora- 
čunom stvaraju potrebe za novim modelima pružanja javnih usluga, točnije, stvaraju širu potrebu razvoja socijalnih inovacija. Razvojem industrije, ubrzavanjem procesa urbanizacije i razvojem tehnologija, socijalne inovacije usko se povezuju i s konceptima socijalnog poduzetništva ili trećeg sektora, koji ih promatraju kao sustave temeljene na reciprocitetu, solidarnosti te odgovorima na promjene.

Uključivanje socijalnih inovacija u službene politike EU-a pokrenulo je niz promjena i prilagodbi regulatornog okvira sa značajnim utjecajem na promicanje trećeg sektora i socijalne ekonomije. Jedna od prvih inicijativa bila je Inicijativa socijalnog poslovanja (European Commission, 2011.) koja je naglasila važnost socijalnog poduzetništva s velikim koristima za platforme i mreže koje ga promoviraju. Pojam socijalnog poduzetništva obuhvaća organizacije i poduzeća koja rade na rješavanju socijalnih pitanja i stoga donose socijalne inovacije (Philips i sur., 2015.). Za razliku od tradicionalnih poduzeća, socijalnim poduzećima se u širem smislu smatraju ona koja svoj uspjeh mjere ne samo financijskim već i socijalnim povratima kroz ostvarivanje svoje misije i ciljeva koji obuhvaćaju služenje zajednici ili specifičnoj grupi ljudi (Baturina, 2013.). Digitalne socijalne inovacije predstavile su drugi važan korak poticanja socijalnih inovacija jer su se tehnološke inovacije i pokretanje poduzeća usmjeravale k rješavanju socijalnih izazova. Paket za socijalna ulaganja donesen je 2013. godine kako bi se pomoglo zemljama članicama u obnovi sustava socijalne zaštite ulaganjem u ljude tijekom njihovog života, a osobito u kritičnim trenucima (djetinjstvo, pronalaženja posla, roditeljstvo i slično).

U svrhu analize i komparacije zemalja prema stupnju razvijenosti i raširenosti socijalnih inovacija 2016. godine provedena je studija koja daje prikaze indeksa socijalnih inovacija za odabrane zemlje (The Econo- mist, 2016.). Indeks socijalnih inovacija za 2016. daje razmjerno značajnu težinu tome jesu li vlade uspostavile podupiruće političko okruženje, te jesu li omogućile financiranje u svrhu procvata socijalnih inovacija. Također, smatra manje značajnim, ali podjednako važnim, karakteristikama razinu poduzetništva i razvijenost civilnog društva, koje su preduvjet za razvoj novih načina rješavanja socijalnih problema. Unutar studije navode se i ograničenja indeksa poput nedovoljne raspoloživosti podataka te zbog toga analiza obuhvaća samo 45 zemalja: G20 i OECD zemlje, zajedno s odabranim ostalim zemljama koje ilustriraju neke zapažene trendove u ekonomijama u razvoju. Uz to kao ograničenje navode i činjenicu da se rezultati moraju tumačiti u domaćem kontekstu jer indeks ne uzima u obzir širinu prekograničnih primjena socijalnih inovacija. Indeks se temelji i uzima u obzir četiri bitna stupa koji zajedno podržavaju sposobnost pojedine zemlje u razvoju socijalnih inovacija; njihov institucionalni i politički okvir, mogućnost financiranja, razinu poduzetništva i konačno dubinu i razvijenost njihovih civilnih društva (The Economist, 2016.). Sjedinjene Američke Države nalaze se na vrhu s indeksom socijalnih inovacija 79/100. Što se tiče zemalja članica Europske unije, Danska je zauzela visoko četvrto mjesto $(71,2)$, Belgija se nalazi na petom mjestu $(69,2)$, Francuska na sedmom mjestu $(66,4)$ te Njemačka zauzima osmo mjesto $(66,0)$. Također, bitno je napomenuti kako studija nije obuhvatila nove zemlje članice EU-a, osim Poljske koja je na dvadeset i prvom mjestu $(52,6)$ što dodatno podupire činjenicu da ove zemlje još uvijek ne dosežu i ne mogu parirati razvijenim tržištima u inoviranju.

Uz pojašnjeni indeks, razvijala su se i različita ostala mjerenja na makrorazini, regionalnoj i mezo razini, a ponekad i na mikrorazini, no ista nisu ušla u širu primjenu. Mjerenje utjecaja socijalnih inovacija iznimno je važno s druge strane u donoše- 
nju odluka u njihovom financiranju, no još uvijek ne postoji jedinstveni okvir, već niz metoda, alata i pristupa za njihovo razumijevanje i mjerenje njihovog društvenog utjecaja (Baturina i Bežovan, 2015.). U mjerenju socijalnih inovacija rijetko se spominje uloga trećeg sektora, koji se uz socijalno poduzetništvo najčešće povezuje sa socijalnim inovacijama u recentnoj literaturi (Baturina i Bežovan, 2015.). Treći sektor tradicionalno ima važnu ulogu u zemljama Europske unije, no globalna ekonomska kriza koja je započela 2008. godine dovela je do smanjenja financiranja trećeg sektora kroz potpore države, a istovremeno i pogoršanja mišljenja javnosti o njihovom radu (Pape i sur., 2020.). Dodatan problem na koji ukazuju istraživanja jest mjerenje performansi i utjecaja trećeg sektora (Anheier et al., 2014.). Pape i sur. (2020.) analiziraju različite utjecaje promjene u politikama nakon posljednje svjetske ekonomske krize prema trećem sektoru na njegovu aktivnost u zemljama EU-a, koje se primarno mogu smatrati posljedicom različitih tradicija ekonomije blagostanja i politika trećeg sektora u Europi. Tako se, primjerice, veličina trećeg sektora povećala u Njemačkoj i Francuskoj, ostala stabilnom u Austriji i Nizozemskoj, dok se smanjila u Španjolskoj, Hrvatskoj i Poljskoj s obzirom na strukturne slabosti njihovih trećih sektora. Također je pritom, posebice kod razvijenih zemalja, došlo do promjene u kompoziciji trećeg sektora, ali i promjene njegove strukture financiranja, u okviru koje sve veći udio imaju tržišni prihodi, dok se smanjuju javna sredstva koja tradicionalno imaju važnu ulogu.

Važno je istaknuti da mnoge dosadašnje analize pokazuju da je uspjeh socijalnih inovacija rezultat socijalnog sustava u kojem poduzetnik djeluje, u smislu podrške i znanja koje dobiva kroz interakciju s ključnim akterima i institucijama (Philips i sur., 2015.). U EU, socijalne su inovacije prepoznate kao politički prioritet te se kontinuirano radi na stvaranju sinergija između razli- čitih politika, donositelja odluka i vanjskih partnera (civilno društvo, privatni i javni sektor). No, nepostojanje jasnog strateškog okvira, neprikladno zakonodavno te društveno i poduzetničko okruženje često djeluju kao prepreke razvoju socijalnih inovacija. Istraživanja na razini EU-a ističu sljedeće prepreke inovacijama (Bureau of European Policy Advisors, 2011.): tradicionalna organizacijska kultura nesklona riziku; zatvoreni sustavi usmjereni na rješavanje pojedinačnih problema bez stvaranja zajedničke svijesti i suradnje; fragmentirani kapacitet i vještine; nedovoljno održivih izvora financiranja kroz čitav inovacijski ciklus.

Kako bi se ostvarila difuzija inovacija, potrebno je zadovoljavanje određenih uvjeta, odnosno potrebno je usklađivanje određenih čimbenika koji mogu poduprijeti širenje i primjenu inovacija. S ekonomskog stajališta, najčešći problemi prilikom širenja socijalnih inovacija su (Social innovation exchange i Young Foundation, 2010.):

- nedostatak kapitala za aktivnosti istraživanja i razvoja (I\&R) i implementaciju

- slabo razvijen sustav zaštite prava vlasništva za socijalne inovacije te posljedično, slabi poticaji za ulaganja

- nesavršena tržišta za socijalne inovacije, što otežava prikupljanje financijskih sredstava.

Dodatno se kao prepreke socijalnim inovacijama prepoznaju (Schulman i Leichsenring, 2015.): (i) rigidno zakonodavstvo i strukturni uvjeti koji ograničavaju kreativno razmišljanje, razvoj suradnje i ideja, (ii) nedostatak vodstva, odnosno nepovoljne hijerarhijske strukture te nedostatak upravljačkog iskustva, (iii) nedostatak uključenosti različitih dionika što uključuje i nedostatak komunikacije, nedostatak suradnje i izgradnje mreže potrebnih za zatvaranje jaza između javnog i privatnog sektora. Pothvati socijalnih inovacija obično započinju kao maleni pothvati u nesva- 
kidašnjim područjima djelovanja te se ne smatraju održivima i stoga ne privlače ulagače. U konačnici to vodi nedostatku izvora financiranja socijalnih poduzetnika i slabo razvijenom tržištu za socijalne inovacije. Još jedna prepreka je nedostatak upravljanja i koordinacije između različitih dionika uključenih u socijalne inovacije. Smanjena svijest o ulozi i doprinosu socijalnih poduzetnika dodatna je prepreka socijalnim inovacijama. Ne postoji zajednički okvir za prepoznavanje važnih sektora i dionika te se socijalni inovatori često ne smatraju dijelom inovacijske kulture. Uz navedeno, postoji nedostatak vještina i programa usavršavanja u području socijalnih inovacija koji vode nedostatku ljudskih resursa te dodatno ograničavaju prepoznavanje socijalnih inovatora kao priznatog zanimanja. Nedostatak podataka i jasne metodologije praćenja i vrednovanja socijalnih inovacija vode različitom shvaćanju i definiranju ovog pojma. Poteškoće u kategoriziranju socijalnih inovacija proizlaze upravo iz velikog broja definicija i širokog shvaćanja pojma. Granice i dionici u procesu socijalnih inovacija nisu homogeno određeni.

Prema pristupu sustavnih promjena, osim navedenih javljaju se i drugi oblici prepreka socijalnim inovacijama. Jedna od takvih je i administrativna kultura koja se još uvijek temelji na pristupu odozgo prema dolje, prema kojem politike određuju političari, a primjenjuju se među građanima (Tepsie, 2014., Schulman i Leichsenring, 2015. i drugi). Ograničavajuće djeluje postojeća kultura među građanima koji smatraju da su društvene promjene pravo i obveza javnog sektora, a građani i drugi dionici imaju tek pasivnu ulogu. Navedeno vodi manjku obrazovanja potrebnog za preuzimanje aktivne uloge građana, podizanje svijesti i jačanja moći svih dionika te njihovo uključivanje u proces promjene društva. Također, navedeno uzrokuje manjak spoznaje o organizacijama civilnog društva i inicijativama koje ciljaju poboljšati kapaci- tete građana za preuzimanje aktivne uloge u oblikovanju politika i lokalnog razvoja.

Još jedna prepreka promjenama je očekivan gubitak. Ljudi se često odupiru reformama, bez obzira koliko one učinkovite bile, zbog toga što očekuju određene gubitke i pogoršanje performansi, barem u kratkom roku. Radikalni inovatori moraju izdržati razdoblje prilagodbe i mogućeg pogoršanja u izvedbi prije nego što se ostvare pozitivni ishodi. Prihvaćanje i interes za promjene često su manji od želje za stabilnošću i održavanjem kontinuiteta. Osim toga, promjene u razmišljanjima predstavljaju značajnu prepreku društvenim promjenama. Što je neki sustav uspješniji i daje ljudima osjećaj sigurnosti i blagostanja, to će postojeće norme postati snažnije utjelovljene u identitet ljudi. Organizacije također ostaju zatočene u rutinama i navikama koje su kako psihološke, tako i praktične prirode. Veze i odnosi između ljudi ili između organizacija i sektora također mogu predstavljati izvor otpora promjenama. Djelovanje privatnog i javnog sektora nerijetko se oslanja na osobne veze koje mogu značiti mnogo više od službenih načina komunikacije i djelovanja.

Navedene prepreke društvenim promjenama mogu se sistematizirati kao unutarnje i vanjske u odnosu na skupinu ili pojedinca (Oganisjana i sur., 2015.). Najčešće unutarnje prepreke su karakteristike, stavovi i razmišljanja ljudi, koji uključuju, primjerice otpor promjenama, slabo razvijene vještine, konzervativno i kratkovidno razmišljanje, manjak pozitivnih iskustava i slično. Vanjske prepreke podložne su složenijim izazovima u okruženju i uključuju: preveliku količinu birokratskih pravila, kompleksno administrativno okruženje i zakonodavstvo, nedostatak kapaciteta za organizacijsko učenje na svim razinama i nedovoljno nezavisnih izvora financiranja.

Unatoč različitim preprekama, unutar Europske unije smatra se da je razvoj so- 
cijalnih inovacija povoljan iz više razloga. Prvo, stvara prilike za jačanje višerazinskog upravljanja. Velik broj socijalnih inovacija započinje na lokalnoj razini na kojoj je lakše identificirati i razumjeti potrebe, ali su potrebni određeni kapaciteti i potpora za njihov razvoj. Osim na lokalnoj, ponekad se razvijaju na regionalnoj ili nacionalnoj razini gdje je važna uloga EU-a u širenju dobrih praksi i poticanju promjena. Uspjeh socijalnih inovacija ovisi o kvaliteti horizontalnih i vertikalnih partnerstava između različitih dionika na različitim razinama, a koordinacijska uloga EU-a može biti od velikog značaja. Drugo, socijalne inovacije mogu djelovati kao važan poticaj za stvaranje nove inovacijske i poduzetničke kulture te stvoriti poveznicu između različitih sektora. Socijalne inovacije također su sastavni dio održivog razvoja koji prožima sve strateške ciljeve i instrumente.

Neke od smjernica za razvoj socijalnih inovacija u EU uključuju (Bureau of European Policy Advisors, 2011.):

- borbu protiv siromaštva, izradom i implementacijom programa koji potiču socijalne inovacije za one najranjivije $u$ društvu, posebice inovativne programe obrazovanja, usavršavanja i zapošljavanja, borbu protiv diskriminacije, te razvoj novih migracijskih politika

- mobiliziranje sredstava za zelenu Europu, što podrazumijeva upravljanje, financiranje, prijenos znanja i iskustava i razvoj novih inicijativa za rješavanje društvenih izazova

- stvaranje društveno-ekonomskih uvjeta i kulture koji djeluju poticajno na razvoj inovativnog društva koje preuzima rizike i tako pronalazi rješenja problema nezaposlenosti i marginalizacije, osigurava visoke zdravstvene i obrazovne standarde te poboljšava kvalitetu života.

Okvirnim programima financiranja EU-a je pokrenula i potaknula različite inicijative za razvoj socijalnih inovacija. Spo- menuta Unija inovacija te program Obzor 2020 neke su od najpoznatijih takvih inicijativa. Pregledom ostalih politika, alata i procesa prepoznati su sljedeći resursi stavljeni na raspolaganje za poticanje socijalnih inovacija u EU (Sabato i sur., 2015.):

- financijski resursi: ponajprije sredstva Europskih strukturnih i investicijskih fondova (ESIF), sredstva namijenjena organizacijama koje djeluju u socijalnoj ekonomiji (izvor su ESI fondovi ili institucije za mikrofinanciranje), sredstva Europskog fonda za ruralni razvoj, EU program za zapošljavanje i socijalne inovacije

- vidljivost i resursi za stvaranje ugleda: sajmovi, konferencije, inicijative za stvaranje poticajnog zakonodavnog okruženja

- umrežavanje i znanje: putem različitih platformi (najpoznatija je Social Innovation Europe Platform), financiranje inicijativa za razvoj vještina i kapaciteta, objavljivanje priručnika, organizacija seminara i drugo.

Novi Europski socijalni fond (ESF+) podržat će socijalne inovacije u zajedničkim i neizravnim okvirima upravljanja (European Commission, 2019.). Novi okvirni program Obzor uključit će socijalne inovacije u sve programske aktivnosti. Fond za katalizaciju inovacija trenutno je pilot projekt u sklopu programa Obzor i njegov je cilj uspostaviti dobre prakse u četiri ili pet zemalja od kojih bi barem neke trebale biti u srednjoj i istočnoj Europi. No, također valja naglasiti potrebu za većom koordinacijom između instrumenata EU-a, kao i drugih nacionalnih i međunarodnih inicijativa. To zahtijeva prepoznavanje $\mathrm{i}$ određivanje prioriteta takvih inicijativa i naknadnih mehanizama ulaganja na nacionalnoj razini. Kontinuirano praćenje i vrednovanje rezultata također je važno. Potrebno je razvijati sustav mjerenja utjecaja kao alata za praćenje socijalnih inovacija, ali i za prikupljanje informacija u 
stvarnom vremenu o tome kako svi čvorovi mreže komuniciraju. Navedene informacije i znanje mogu doprinijeti boljem upravljanju i ukazati kako potaknuti ključne sudionike u mreži, građane, institucije i poduzeća da učinkovito inoviraju kako bi ostvarili utjecaj i bili spremni na vanjske izazove.

Istovremeno, preporučuje se smanjiti broj programa i poziva te objediniti glavna pravila sudjelovanja, smanjiti birokraciju i vrijeme potrebno za donošenja odluka o financiranju te osigurati veću fleksibilnost. U budućnosti se planira i osnivanje Europske agencije za socijalne inovacije koja bi koordinirala, financirala $i$ širila znanje o socijalnim inovacijama.

Tri se načela izdvajaju kao temelj za buduće socijalne inovacije u Europi (Addarii i Lipparini, 2017.):
- usmjerenost na ljude, jer ljudi su najbolji izvor inovacija i ciljni korisnici. Potrebno je ulagati u ljude kako bi oblikovali i potaknuli inovacije u skladu s njihovim potrebama i vrijednostima. Potrebno je, također, definirati osnovu javnog blagostanja diljem Europe i poticati ga.

- sustav usmjeren na pretvaranje potencijala ljudi i institucija u pozitivne rezultate, ističući socijalne inovacije na razini gradova i regija kao velikih izvora inovacija

- socijalne inovacije u središtu kreiranja politika i političkog programa Europe.

U tablici 1. dan je pregled odabranih europskih inicijativa za poticanje inovacija te su na temelju svega navedenog sažete prepreke, kao i preporuke za budući razvoj socijalnih inovacija.

Tablica 1.

Pregled prepreka, preporuka i inicijativa za razvoj socijalnih inovacija u EU

\begin{tabular}{|c|c|c|c|}
\hline \multicolumn{2}{|c|}{ Strateški okvir } & \multirow[b]{2}{*}{ Prepreke } & \multirow[b]{2}{*}{ Preporuke } \\
\hline $\begin{array}{c}\text { Strateške smjernice } i \\
\text { financiranje }\end{array}$ & Fokusirane inicijative & & \\
\hline Europa 2020 & $\begin{array}{l}\text { Mladi u pokretu (eng. Yo- } \\
\text { uth on the move) }\end{array}$ & $\begin{array}{l}\text { - tradicionalna organi- } \\
\text { zacijska kultura ne- } \\
\text { sklona riziku }\end{array}$ & $\begin{array}{l}\text { - poticati ulaganja u } \\
\text { inovativne programe } \\
\text { obrazovanja, usavrša- } \\
\text { vanja i zapošljavanja }\end{array}$ \\
\hline $\begin{array}{l}\text { Europski stup socijalnih } \\
\text { prava }\end{array}$ & $\begin{array}{l}\text { Digitalna agenda za Eu- } \\
\text { ropu (eng. Digital Europe } \\
\text { Agenda) }\end{array}$ & $\begin{array}{l}\text { - zatvoreni sustavi } \\
\text { usmjereni na rješava- } \\
\text { nje pojedinačnih pro- } \\
\text { blema bez stvaranja } \\
\text { zajedničke svijesti i } \\
\text { suradnje }\end{array}$ & $\begin{array}{l}\text { - povećavati vidljivost } \\
\text { i svijest o socijalnim } \\
\text { inovacijama (natjeca- } \\
\text { nja i stvaranje konku- } \\
\text { rencije) }\end{array}$ \\
\hline $\begin{array}{l}\text { Okvirni program za istra- } \\
\text { živanje i razvoj }\end{array}$ & $\begin{array}{l}\text { Resursno-učinkovita Eu- } \\
\text { ropa (eng. Resource-ef- } \\
\text { ficient Europe) }\end{array}$ & $\begin{array}{l}\text { - nedovoljno održivih } \\
\text { izvora financiranja } \\
\text { kroz čitav inovacijski } \\
\text { ciklus }\end{array}$ & $\begin{array}{l}\text { - stvaranje poticajnog } \\
\text { okruženja putem je- } \\
\text { dinstvenog tržišta, } \\
\text { inicijative za socijalno } \\
\text { poslovanje i sličnih } \\
\text { inicijativa EU-a } \\
\end{array}$ \\
\hline $\begin{array}{l}\text { Okvirni program za kon- } \\
\text { kurentnost i inovacije }\end{array}$ & $\begin{array}{l}\text { Zajednički centar za } \\
\text { istraživanja (eng. Joint } \\
\text { Research Center) }\end{array}$ & $\begin{array}{l}\text { - nedostatak vještina i } \\
\text { programa usavršava- } \\
\text { nja u području socijal- } \\
\text { nih inovacija }\end{array}$ & $\begin{array}{l}\text { - umrežavanje, priku- } \\
\text { pljanje i širenje infor- } \\
\text { macija }\end{array}$ \\
\hline Strukturni fondovi & $\begin{array}{l}\text { Inicijativa socijalnog po- } \\
\text { slovanja (eng. Social Bu- } \\
\text { siness) }\end{array}$ & $\begin{array}{l}\text { - konzervativno i krat- } \\
\text { kovidno razmišljanje }\end{array}$ & $\begin{array}{l}\text { - poticanje i financira- } \\
\text { nje inicijativa za razvoj } \\
\text { vještina i kapaciteta }\end{array}$ \\
\hline
\end{tabular}


Tablica 1 - nastavak

\begin{tabular}{|c|c|c|c|}
\hline \multicolumn{2}{|c|}{ Strateški okvir } & \multirow[b]{2}{*}{ Prepreke } & \multirow[b]{2}{*}{ Preporuke } \\
\hline $\begin{array}{c}\text { Strateške smjernice } i \\
\text { financiranje }\end{array}$ & Fokusirane inicijative & & \\
\hline $\begin{array}{l}\text { Unija inovacija (eng. In- } \\
\text { novation Union) }\end{array}$ & $\begin{array}{l}\text { Shema "Tvoj prvi posao« } \\
\text { (eng. Your First EURES } \\
\text { Job } \\
\text { Scheme) }\end{array}$ & \multirow{4}{*}{$\begin{array}{l}\text { - slabo razvijen sustav } \\
\text { zaštite prava vlasniš- } \\
\text { tva za socijalne inova- } \\
\text { cije }\end{array}$} & $\begin{array}{l}\text { - politike i strateški } \\
\text { okvir koji prepoznaje } \\
\text { važnost socijalnih ino- } \\
\text { vacija }\end{array}$ \\
\hline $\begin{array}{l}\text { Program za zapošljava- } \\
\text { nje i socijalne inovacije }\end{array}$ & $\begin{array}{l}\text { Projekt zajednice so- } \\
\text { cijalnih inovacija (eng. } \\
\text { Social Innovation Com- } \\
\text { munity project) }\end{array}$ & & \multirow{3}{*}{$\begin{array}{l}\text { - razvijati instrumente } \\
\text { za razvoj kapaciteta } \\
\text { (mapiranje, baze po- } \\
\text { dataka, nagrade) }\end{array}$} \\
\hline $\begin{array}{l}\text { Paket ulaganja u socijal- } \\
\text { ne inovacije (eng. Social } \\
\text { Investment Package) }\end{array}$ & $\begin{array}{l}\text { Platforma za socijalne } \\
\text { inovacije (eng. Social } \\
\text { Innovation Europe plat- } \\
\text { form) }\end{array}$ & & \\
\hline $\begin{array}{l}\text { Mikrofinanciranje (po- } \\
\text { put Social Impact Ac- } \\
\text { celerator) }\end{array}$ & Liv & & \\
\hline
\end{tabular}

Izvor: izrada autora.

Može se zaključiti da će upravo socijalne inovacije postati važan strateški cilj zemalja članica, posebice ako se uzme u obzir da Europska unija aktivno promiče pristup peterostruke uzvojnice prepoznajući održivi razvoj i inovacije kao ključne razvojne prioritete.

\section{ZAKLJUČAK}

U vrijeme digitalizacije i brzih promjena koje utječu na potrebe, uvjete i način življenja ljudi te obavljanje aktivnosti, zemlje članice Europske unije susreću se s novim društvenim i gospodarskim izazovima. Za uspješnu provedbu razvojnih strategija Europske unije potreban je jači okvir upravljanja, više političke predanosti te posebno veća uključenost europskih građana. Uključivanje javnosti i civilnog društva ključno je u izgradnji povjerenja u javne institucije, društveni kapital i društvenu koheziju, pri donošenju odluka te raspodjeli i primjeni resursa. Upravo su društvene inovacije nerijetko posljedica suradnje između različitih sektora.
Osobito kad je riječ o javnom sektoru važno je uključiti građane u proces kreiranja društvenih inovacija koje su postale važan način odgovora na suvremene društvene izazove. Razvoj društvenih inovacija zahtijeva veću fleksibilnost, odnosno smanjivanje administrativnih prepreka, otvorenost prema društvu te poticanje suradnje i dijeljenje znanja.

Potrebno je unaprijediti koordinaciju različitih instrumenata EU-a te razviti alate pomoću kojih će se pratiti i povezivati različite regionalne i nacionalne inicijative kako bi se postiglo sinergijsko djelovanje i stvorili novi poticaji inovacijama. U cilju održavanja konkurentnosti zemlje bi trebale razviti inovacijske strategije i ciljeve koji će integrirati različite dionike i javno mnijenje u procese stvaranja znanja, politika, vrijednosti i normi temeljenih na bliskom dijalogu s građanima. Osim unutar integracije, potrebno je razvijati međunarodnu suradnju te razviti mehanizme pomoću kojih bi se prepoznale prilike, sličnosti i razlike $\mathrm{u}$ istraživačkim ciljevima kao i potencijalne ko- 
risti i rizike za europski vrijednosni lanac. Socijalne inovacije ne mogu se ostvariti bez okupljanja svih dionika, razvoja kolektivnog mentaliteta, horizontalne izgradnje kapaciteta te usvajanja novih načina djelovanja politike i poticanja javno-privatnih partnerstva. Stvaranje poticajnog okruženja i inovacijske kulture nužni su uvjeti za daljnji razvoj socijalnih inovacija koje su postale imperativom za zadovoljavanje potreba stanovništva i povećanja blagostanja u vrijeme Četvrte industrijske revolucije

Glavno ograničenje ovog istraživanja je činjenica da je empirijska literatura kao i dostupnost podataka u ovome području vrlo ograničena te se analiza i zaključci ovog rada uglavnom se temelje na teorijskoj literaturi i kompilaciji dosadašnjih, većinom kvalitativnih rezultata istraživanja. Kako bi se poboljšalo razumijevanje razine i uloge socijalnih inovacija te omogućilo što efikasnije alociranje poticaja za iste, nužna su daljnja istraživanja u cilju formiranja metodološkog okvira za mjerenje socijalnih inovacija na različitim razinama.

\section{LITERATURA}

Adams, D., \& Hess, M. (2010). Social innovation and why it has policy significance. The Economic and Labour Relations Review, 21(2), 139-155. https:// doi.org/10.1177/103530461002100209

Addarii, F., \& Lipparini, F. (2017). Vision and trends of social innovation for Europe. Luxembourg: Publications Office of the European Union.

Angelidou, M., \& Psaltoglou, A. (2017). An empirical investigation of social innovation initiatives for sustainable urban development. Sustainable Cities and Society, 33, 113-125. https://doi.org/10.1016/j.scs.2017.05.016

Anheier, H. K., Krlev, G., Preuss, S., Mildenberger, G., Bekkers, R., Mensink, W., Bauer, A., Knapp, M., Wistow, G., Hernandez, A., \& Bayo, A. (2014). Social innovation as impact of the Third Sector. Deliverable 1.1 of the project: Impact of the Third Sector as Social Innovation (ITSSOIN), European Commission - 7th Framework Programme. Available at http://itssoin.eu/site/ wp-content/uploads/2015/09/ITSSOIN_D1_1_ Social-Innovation-as-Impact.pdf
Asian Development Bank. (2009). Technology and innovation. Enterprise in Asia: fostering dynamism in SME's. Manilla: ADB.

Astakhova, K. V., Korobeev, A. I., Prokhorova, V. V., Kolupaev, A. A., Vorotnoy, M. V., \& Kucheryavaya, E. R. (2016). The role of education in economic and social development of the country. International Review of Management and Marketing, 6(S1), 53-58. https://econjournals. com/index.php/irmm/article/view/1865

Aubert, J. E. (2005). Promoting innovation in developing countries: A conceptual framework. Washington, D.C.: The World Bank.

Avelino, F., Wittmayer, J. M., Pel, B., Weaver, P., Dumitru, A., Haxeltine, A., \& O'Riordan, T. (2019). Transformative social innovation and (dis)empowerment. Technological Forecasting and Social Change, 145, 195-206. https://doi.org/10.1016/j. techfore.2017.05.002

Baturina, D. (2014). WILCO FP7 projekt; što smo naučili i što nosi budućnost?. Revija za socijalnu politiku, 21(1), 89-94. https://doi.org/10.3935/ rsp.v21i1.1211

Baturina, D., \& Bežovan, G. (2015). Social innovation impact-review of research. Seventh Framework Programme (grant agreement 613034), Working paper No. 9, European Union. Brussels: Third Sector Impact.

Bežovan, G., Matančević, J., \& Baturina, D. (2016). Socijalne inovacije kao doprinos jačanju socijalne kohezije i ublažavanju socijalne krize u europskim urbanim socijalnim programima. Revija za socijalnu politiku, 23(1), 61-80. https:// doi.org/10.3935/rsp.v23i1.1279

Bosworth, G., Rizzo, F., Marquardt, D., Strijker, D., Haartsen, T., \& Aagaard Thuesen, A. (2016). Identifying social innovations in European local rural development initiatives. Innovation: The European Journal of Social Science Research, 29(4), 442461.https://doi.org/10.1080/13511610.2016.1176555

Buhr, D. (2015). Social innovation policy for Industry 4.0. Friedrich-Ebert-Stiftung, Division for Social and Economic Policies.

Bureau of European Policy Advisors. (2011). Empowering people, driving change. Social innovation in the European Union. Luxembourg: Publications office of the European Union.

Carayannis, E. G., Barth, T. D., \& Campbell, D. F. (2012). The Quintuple Helix innovation model: global warming as a challenge and driver for innovation. Journal of innovation and entrepreneurship, 1(1), 1-12. https://doi.org/10.1186/2192-5372-1-1

Clark, C., Rosenzweig, W., Long, D., \& Olsen, S. (2004). Double bottom line project report: As- 
sessing social impact in double bottom line ventures; methods catalog. Available at https:// escholarship.org/uc/item/80n4f1mf

Dees, J. G., Anderson, B. B., \& Wei-Skillern, J. (2004). Scaling social impact: Strategies for spreading social innovations. Stanford Social Innovation Review, 1(4), 14-32. https://ssir.org/ articles/entry/scaling_social_impact\#

Department for Business, Energy \& Industrial Strategy. (2018). UK Position paper on the ninth EU framework programme for research and innovation (FP9). London

Emerson, J., Wachowicz, J., \& Chun, S. (2000). Social return on investment: Exploring aspects of value creation in the non-profit sector. San Francisco: The Roberts Foundation.

European Commission. (2009). EU budget 2008. Financial report. Luxembourg: Publications office of the European Union.

European Commission. (2010). Europe 2020. A strategy for smart, sustainable and inclusive growth. Communication from the Commission, COM(2010)2020. Brussels: European Commission.

European Commission. (2013). Innovation Union. A pocket guide on the Innovation Union. Brussels: European Union.

European Commission. (2014). Social innovation theory and research. A guide for researchers. Brussels: European Commission.

European Commission. (2016). EU budget 2015. Financial report. Luxembourg: Publications office of the European Union.

European Commission. (2018). EU budget for the future. Available at http://ec.europa.eu/budget/ mff/index_en.cfm

European Commission. (2019a). The role of social innovation in addressing social challenges. Available at https://europa.eu/regions-and-cities/ programme/sessions/608_en

European Comission. (2019b). European Innovation Scoreboard. Available at https:/ec.europa.eu/ growth/industry/policy/innovation/scoreboards_en

Flanagan, K., Uyarra, E., \& Laranja, M. (2011). Reconceptualising the 'policy mix' for innovation. Research Policy, 40(5), 702-713. https://doi.org/10.1016/j.respol.2011.02.005

Gentile, M. C. (2000). Social impact management, a definition. Discussion Paper II. Aspen: The Aspen Institute.

Gilbert, J. P., Light, R. J., \& Mosteller, F. (1975). Assessing social innovations: An empirical base for policy. In C. A. Bennett (Ed.), Evaluation and experiment: Some critical issues in assessing social programs (pp. 39-193). Cambridge, MA: Academic Press.

Griggs, D., Stafford-Smith, M., Gaffney, O., Rockström, J., Öhman, M. C., Shyamsundar, P., Steffen, W., Glaser, G., Kanie, N., \& Noble, I. (2013). Sustainable development goals for people and planet. Nature, 495(7441), 305-307. https:// doi.org/10.1038/495305a

Grimm, R., Fox, C., Baines, S., \& Albertson, K. (2013). Social innovation, an answer to contemporary societal challenges? Locating the concept in theory and practice. Innovation: The European Journal of Social Science Research, 26(4), 436-455.https:// doi.org/10.1080/13511610.2013.848163

Hasan, I. (2010). The innovation-economic growth nexus: Global evidence. Research policy, 39(10), 1264-1276. https://doi.org/10.1016/j.respol.2010.07.005

Heiskala, R. (2007). Social innovations: Structural and power perspectives. In T. J. Hämäläinen \& R. Heiskala (Eds.), Social innovations, institutional change and economic performance (pp. 52-79). Cheltenham: Edward Elgar.

Höpker, L. (2013). The chances of success of the Europe 2020 Strategy - An analysis against the background of the Lisbon Strategy. Study Paper No 4/13. Europa-Kolleg Hamburg Institute for European Integration.

Midgley, J. (1995). Social development: The developmental perspective in social welfare. London: Sage.

Morrar, R., Arman, H., \& Mousa, S. (2017). The fourth industrial revolution (Industry 4.0): A social innovation perspective. Technology Innovation Management Review, 7(11), 12-20. https://doi. org/10.22215/timreview/1117

Moulaert, F. (2016). Social innovation: Institutionally embedded, territorially (re) produced. In D. MacCallum, F. Moulaert, J. Hillier \& S. Vicari Haddock (Eds.), Social innovation and territorial development (pp. 27-40). London: Routledge.

Moulaert, F., MacCallum, D., \& Mehmood, A. (2013). The International Handbook on Social Innovation. Cheltenham: Edward Elgar.

Mumford, M. D., \& Moertl, P. (2003). Cases of social innovation: Lessons from two innovations in the 20th century. Creativity Research Journal, 15(2-3), 261-266. https://doi.org/10.1207/ S15326934CRJ152\&3_16

Murray, R., Caulier-Grice, J., \& Mulgan, G. (2010). The Open Book of Social Innovation. London: NESTA.

Nadiri, I. (1993). Innovations and Technological Spillovers. Working Paper 423. Cambridge, MA: National Bureau of Economic Research. 
Neumeier, S. (2012). Why do social innovations in rural development matter and should they be considered more seriously in rural development research? - Proposal for a stronger focus on social innovations in rural development research. Sociologia ruralis, 52(1), 48-69. https://doi.org/10.1111/j.1467-9523.2011.00553.x

Nicholls, A, Murdock, A. (2012). Social Innovation: Blurring Boundaries to Reconfigure Markets, Hamshire: Palgrave Macmillan.

Organisation for Economic Co-operation and Development. (2010). Social entrepreneurship and social innovation. Paris: OECD Publishing.

Organisation for Economic Co-operation and Development. (2012). Innovation for development. Paris: OECD Publishing.

Oganisjana, K., Surikova, S., \& Laizans, T. (2015). Factors influencing social innovation processes in Latvia: Qualitative research perspective. Entrepreneurship and Sustainability Issues, 3(2), 186-197. https://doi.org/10.9770/jesi.2015.3.2(6)

Pape, U., Brandsen, T., Pahl, J. B., Pielinski, B., Baturina, D., Brookes, N., Chaves-Avila, R., Kendall, J., Matančević, J., Petrella, F., Rentzch, C., Richez- Battesti, N., Savall-Morera, T., Simsa, R., \& Zimmer, A. (2020). Changing policy environments in Europe and the resilience of the third sector. Voluntas, 31, 238-249. https://doi. org/10.1007/s11266-018-00087-z

Pavlišić, P. (2016). Inovacije i gospodarski rast: koliko je jaka povezanost? Primjer njemačkog gospodarstva. Ekonomski pregled, 67(5), 440-461. https://hrcak.srce.hr/170981

Phillips, W., Lee, H., Ghobadian, A., O’Regan, N., \& James, P. (2015). Social innovation and social entrepreneurship: A systematic review. Group \& Organization Management, 40(3), 428-461. https://doi.org/10.1177/1059601114560063

Phills, Jr. J. R., Deiglmeier, K., \& Miller, D. T. (2008). Rediscovering social innovation. Stanford Social Innovation Review, 6(4), 34-43. https://ssir.org/ articles/entry/rediscovering_social_innovation\#

Pisano, U., Lange, L., \& Berger, G. (2015). Social innovation in Europe. An overview of the concept of social innovation in the context of European initiatives and practices. European Sustainable Development Network.

Pol, E., \& Ville, S. (2009). Social innovation: Buzz word or enduring term?. The Journal of Socio-Economics, 38(6), 878-885. https://doi.org/10.1016/j.socec.2009.02.011

Reynolds, S., Gabriel, M., \& Heals, C. (2016). Social innovation policy in Europe: where next? Annual State of the Union Report-Part 1. Social Inno- vation Community. Available at https://www. siceurope.eu/sites/default/files/field/attachment/ social_innovation_policy_in_europe_-_where_next.pdf

Sabato, S., Vanhercke, B., \& Verschraegen, G. (2015). The EU framework for social innovation - between entrepreneurship and policy experimentation. ImPRovE Working Papers 15/21. Antwerp: Herman Deleeck Centre for Social Policy.

Sachs, J. D. (2012). From millennium development goals to sustainable development goals. The Lancet, 379(9832), 2206-2211. https://doi. org/10.1016/S0140-6736(12)60685-0

Schulman, K., \& Leichsenring, K. (2015). A qualitative inventory of the key drivers of social innovation in social support and long-term care. Final report. Vienna: Mopact.

Schumpeter, J. A. (1939). Business cycles: A theoretical, historical and statistical analysis of the capitalist process (Vol. 1). New York: McGraw-Hill.

Social Innovation Exchange \& Young Foundation. (2010). Study on social innovation. The Young Foundation.

Solow, R. (1956). A contribution to the theory of economic growth. The Quarterly Journal of Economics, 70(1), 65-94. https://doi. org/10.2307/1884513

Spiesberger, M., Gomez Prieto, J., \& Seigneur, I. (2018). Smart specialization and social innovation: from policy relations to opportunities and challenges. S3 policy briefs series, No 24/2018. Luxembourg: Publications office of the European Union.

Tajani, A., Ratas, J., \& Juncker, J. C. (2017). Europski stup socijalnih prava. Europski parlament, Vijeće i Komisija. Luxembourg: Ured za publikacije EU.

The Economist. (2016). Social Innovation Index 2016. Available at https://eiuperspectives.economist.com/technology-innovation/old-problems-new-solutions-measuring-capacity-social-innovation-across-world-0

Ulku, H. (2004). R\&D, innovation, and economic growth: An empirical analysis. International Monetary Fund Working Papers, WP/04/185.

United Nations. (2015). Sustainable development goals. Available at https://www.un.org/sustainabledevelopment/sustainable-development-goals/

van Wijk, J., Zietsma, C., Dorado, S., de Bakker, F. G., \& Martí, I. (2019). Social innovation: Integrating micro, meso, and macro level insights from institutional theory. Business \& Society, 58(5), 887918. https://doi.org/10.1177/0007650318789104 


\title{
Summary
}

\section{SOCIAL INNOVATION AS AN IMPORTANT ELEMENT OF EUROPEAN DEVELOPMENT STRATEGIES}

\author{
Sanja Franc, Antea Barišić \\ The Faculty of Economics \& Business, University of Zagreb, \\ Zagreb, Croatia \\ Petra Palić \\ Department of Sociology, Croatian Catholic University, \\ Zagreb, Croatia
}

\begin{abstract}
EU member states are undergoing the process of economic and demographic transformation with significant influence on society and economy. In order to respond to the existing and future challenges, it is necessary to adapt development strategies and policies, as well as to focus on concepts such as innovation, social change, equality and sustainable development. In the new development strategy, EU will focus on creating a society that will function as a competitive, secure and energy-efficient system. Scientists, economic policy makers, nongovernmental organisations and entrepreneurs are showing an increasing interest in the field of social innovation, striving to address a series of contemporary challenges. The aim of this paper is to study the role and ways offostering social innovations in the European Union. The contribution of this paper is reflected in the systematic review of the importance of social innovation and the measures used to foster them, while pointing out the existing obstacles and needs and recommendations for further development of social innovation in the context of global challenges that the EU is facing. The results of the research indicate the growing importance of social innovation in modern EU policies that actively promote the quintuple helix approach, recognizing sustainable development and innovation as key development priorities during the Fourth Industrial Revolution. Recommendations for further development of social innovation in the EU include the need to coordinate various EU instruments in this area, encourage investment in innovative education, training and employment programs in this area, increase awareness of social innovation, encourage networking and dissemination of information and create an enabling environment for their development. Also, the paper highlights the shortcomings in the field of measuring social innovation, as well as the need to address this challenge, in order to improve the understanding of their role, but also a more efficient allocation of incentives to them.
\end{abstract}

Key words: social innovation, European Union, strategic framework, development strategies. 